THE TEIN-CHING, OR CHINESE INDIGO.

When in the north of China my attention was directed to a plant largely cultivated by the inhabitants for the sake of its blue dye. In the southern provinces a considerable quantity of indigo (Indigofera) is cultivated and manufactured, besides a large portion which is annually imported from Manilla and the Straits. In the north, however, the plant which we call indigo is never met with-owing, I suppose, to the coldness of the winters - but its place is supplied by this Isatis indigotica, or the "Tein-ching," as it is called by the Chinese. I met with it in the Nanking cotton district, a few miles west from Shanghae, where it is considered a plant of great importance, and covers a large tract of country. It is grown in rows a few inches apart, and at a distance looks like a field of young turnip or cabbage plants. In June 1844, when I was in that country, the plants were from 6 inches to 1 foot in height, and being considered in perfection, the natives were busily employed in cutting them and removing them to the manufactory. One of these places which I inspected was close on the banks of the canal, and was placed there for the convenience of the farmers, who brought their leaves in boats from the surrounding country, as well as to be near the water, a large quantity of which was requisite in the manufacture. It consisted of a number of round tanks, which are built for the purpose of steeping the leaves. The leaves are thrown into the tanks and covered with water, and, after remaining for a certain length of time, the juice is drawn off into other tanks, where I believe it is mixed with lime. The colour of the liquid at first is a kind of greenish blue, but after being well stirred up and exposed to the air it becomes much darker and very like the well-known indigo of commerce. I suppose it is thickened afterwards by evaporation in some way, but that part of the process did not come under my observa: tion. I am very much inclined to believe that this is the dye used to colour the green teas which are manufactured in the north of China for the English and American markets; this, however, is only conjecture. The plant has a half-shrubby stem covered with a fine bloom. Its root-leaves are oval-lanceolate, on long stalks, sharppointed, slightly toothed, and somewhat fleshy ; those on the upper part of the stem, near the flowers, are linear. The stem is decumbent, a foot and a half long, and divided at its extremity into several drooping racemes about 6 inches long; on its sides it bears here and there small clusters of leaves like those of the root. Flowers very small, yellow. Silicles black, quite smooth, 6 lines long by 2 wide in the broadest part, oblong, obtuse at each end, a little contracted below the middle, with a thin edge and a single median line.-Fortune, in Journal of the Horticultural Society.

\title{
M. SCHÖNHERR.
}

M. Schönherr the celebrated Swedish entomologist has had a distinguished mark of royal favour conferred upon him in November last by being made Knight Commander of the Royal Order of Wasa, having previously in 1829 by the late King of Sweden been made Knight of the Royal Order of the Polar Star. 


\section{$2 \mathrm{BHL}$ Biodiversity Heritage Library}

1847. "The Tein-ching, or Chinese Indigo." The Annals and magazine of natural history; zoology, botany, and geology 19, 139-139. https://doi.org/10.1080/037454809496467.

View This Item Online: $\underline{\text { https://www.biodiversitylibrary.org/item/19437 }}$

DOI: https://doi.org/10.1080/037454809496467

Permalink: https://www.biodiversitylibrary.org/partpdf/18916

\section{Holding Institution}

Natural History Museum Library, London

\section{Sponsored by}

Natural History Museum Library, London

\section{Copyright \& Reuse}

Copyright Status: Public domain. The BHL considers that this work is no longer under copyright protection.

This document was created from content at the Biodiversity Heritage Library, the world's largest open access digital library for biodiversity literature and archives. Visit BHL at https://www.biodiversitylibrary.org. 